\title{
Immunological Model and Otological Manifestations of Behçet's Disease
}

\author{
A. Greco, C. Marinelli, A. Gallo, M. Fusconi, G.F. Macri, A. De Virgilio, S. Martellucci and \\ M. de Vincentiis
}

Department Organs of Sense - ENT Section - University of Rome “La Sapienza”, Italy

\begin{abstract}
Behçet's disease (BD) is an autoimmune vasculitis of unknown aetiology that is characterised by relapsing episodes of oral aphthous ulcers, genital ulcers, ocular lesions, skin lesions, and other manifestations, including vascular, gastrointestinal and neurological involvement.

Behçet's disease exists worldwide, although there are significant regional differences, with the highest number of incidences in the Mediterranean, Middle East, and Far East. Behçet's disease occurs mainly between 18 and 40 years of age, and the male-to-female ratio is $7: 1$.

The cause of Behçet's disease is unknown. It is believed to be due to an autoimmune process triggered by an infectious or environmental agent (possibly local to a geographic region) in a genetically predisposed individual.

$\mathrm{T}$ cell homeostasis perturbation, especially Th1 and Th17 expansions and decrease regulation by Tregs are now supposed to be the cornerstone of BD pathogenesis. Inflammatory cytokine such as IL21 plays a critical role in pathogenesis of BD.

Inner ear involvement in Behçet's disease was first reported by Alajouanine in 1961. Thereafter, many cases of inner ear involvement were described by other authors. The otological features of Behçet's disease can be divided into hearing loss and disequilibrium.

The incidence of hearing loss in Behçet's disease has been reported to be 12 to $80 \%$ in several studies in the literature. Recently, some authors observed a significant percentage $(59.2 \%)$ of hearing loss associated with Behçet's disease. According to other studies, hearing loss can be the fourth or even the third most common manifestation of the disease.

The treatment of inner ear lesions remains unsatisfactory and is based on immunosuppressive agents and will not be reviewed here.

This review focuses on the etiophatogenesis and otological manifestations of Behçet's disease and specifies the role of the otorhinolaryngologist as an integral member of the multidisciplinary team for clinical management of these patients.
\end{abstract}

Keywords: Autoimmunity, Behçet's disease, hearing loss, immunology, muco-cutaneous ulcerations, neurological symptoms, uveitis, vascular symptoms, vasculitis, vertigo.

\section{TAKE-HOME MESSAGE}

- Behcet'disease is characterized by a perturbation of $\mathrm{T}$ cells homeostasis characterized by Th1 and Th17 polarization and decreased activated memory Tregs. IL21 produced by CD4+ activated cells has a critical role in modulation of $\mathrm{T}$ cell homeostasis. Inflammatory lesions are mediated by cytotoxic $\mathrm{T}$ cells and neutrophils.

- The diagnosis of Behçet's disease is based on clinical criteria. Major signs include aphthous-like ulcerations of the oral mucosa, genital ulcerations, and uveitis. However, recent studies have shown that hearing loss will be the fourth and even the third most common manifestation of the disease.

*Address correspondence to this author at the LGO Valerio Bacigalupo 32 C, 00142 Rome, Italy; Tel: (+39)347/8404236;

E-mail: giano1979@hotmail.com
- Generally, Behçet's disease is detected by a dermatologist or an ophthalmologist; however, in the presence of otological manifestations, such as hearing loss or disequilibrium, the otorhinolaryngologist could be the first clinician to suspect and diagnose this illness.

\section{INTRODUCTION}

Behçet's disease (BD) is a systemic inflammatory vasculitis of unknown aetiology, characterised by relapsing episodes of oral aphthous ulcers, genital ulcers, ocular lesions, skin lesions, and other manifestations, including vascular, gastrointestinal and neurological involvement [1].

First description of BD, also known as the Old Silk Road disease, has been attributed to Hippocrates in the $5^{\text {th }}$ century BC in the "Third book of endemic diseases" [2]. In 1937, Behçet, a Turkish dermatologist, identified the 3 major signs (recurrent oral aphtae, genital ulcerations, recurrent uveitis) and grouped them into a clinical entity $[3,4]$. However, six years prior to Behçet's description, Adamantiades, a Greek physician, was reported to have published an account of the 
disease in a French journal [5]. The disease complex became known as Adamantiades-Behçet's disease, although this term is rarely used today.

Behçet's disease exists worldwide, although there are significant regional differences, with the highest number of incidences in the Mediterranean, Middle East, and Far East [6]. Behçet's disease is associated with the ancient trading route known as the "Silk Road", which extends from Eastern Asia to the Mediterranean basin. Behçet's disease occurs most frequently between the latitudes $30^{\circ}$ and $45^{\circ} \mathrm{N}$ in Eurasian populations [7, 8] (Fig. 1).

However, there are reports of Behçet's disease (BD) from other parts of the world with total reports of less than 200 patients $[9,10]$.

The prevalence of BD is 80 to 370 cases per 100,000 population in Turkey, 10/100,000 in Japan and 0.6/100,000 in Yorkshire. European cases are more often described, not exclusively in the migrant population [11]. Behçet's disease occurs mainly between 18 and 40 years. Some paediatric onset cases have been reported [12]. After 55 years, the onset of Behçet's disease is exceptional, and a diagnosis has to be made very cautiously.

The male-to-female ratio is $7: 1$ in symptomatic forms; however, women predominate over men in studies where less symptomatic forms are systematically sought and included [13].

\section{Etiophatogenesis}

The cause of BD is unknown. It is believed to be due to an autoimmune process triggered by an infectious or environmental agent (possibly local to a geographic region) in a genetically predisposed individual $[14,15]$

\section{Genetics}

Human Major Histocompatibility Complex (MHC) is the region of the genome the most strongly associated with autoimmune diseases [16]. The Human Leukocyte Antigen (HLA)-B51 allele located in the MHC locus, on chromosome $6 \mathrm{p}$ has been the most strongly associated risk factor for BD in areas along the Old Silk Road, with a stronger association in Turkish and Japanese patients compared with Caucasians [7]. However, the highest contribution of the HLA-B51 to the overall genetic susceptibility is estimated to be around $20 \%$, meaning other loci outside the MHC complex must be implicated.

\section{Environment}

Individuals from endemic areas who have immigrated to areas with a low prevalence of the disease have an intermediate risk for developing the disease, indicating that the environment plays some role in BD [1, 17]. Several microorganisms have been implicated in the aetiology of BD, Herpes simplex virus-1 and Streptococcus sanguis $[7,18,19]$. However, to date, there is no information supporting the role of a single microorganism as the specific aetiologic agent [20].

The most generally accepted theory for the role of infectious agents is that microorganism antigens have high homology with human proteins (like heat shock protein (HSP) 65, obtained from Mycobacterium, which has high homology with human protein HSP60) and that crossreaction leads to immune response [21,22].

\section{Immunity}

Anti-endothelial cell antibodies (AECAs) have been described in many vasculitides, including Behcet's disease,

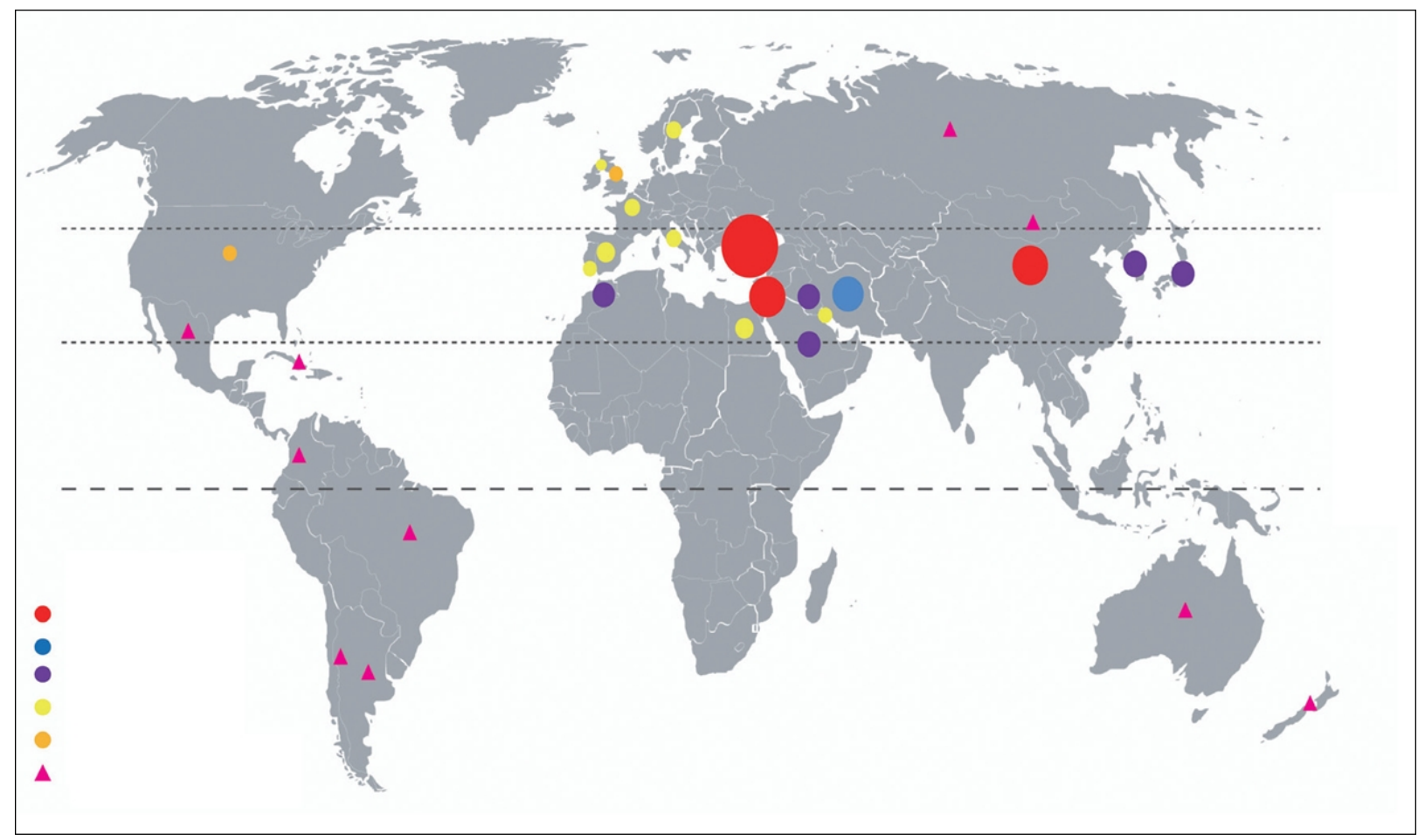

Fig. (1). Cho SB, Cho S, Bang D. Global distribution of Behçet's disease. Dot size reflects prevalence. New insights in the clinical understanding of Behçet's disease. Yonsei Med J 2012; 53: 35-42. 
and their presence has been linked to pathogenesis [23]. Taken together, the level of evidence for the implication of autoantibodies in BD pathogenesis is low.

$\mathrm{T}$ lymphocytes have an activated phenotype in $\mathrm{BD}$ and produce inflammatory cytokines, acting as the major lymphocytes implicated in BD pathogenesis. The discovery of new T-cell subpopulations in recent years has shed further light on BD pathogenesis. Numerous perturbations in $\mathrm{T}$ cell homeostasis have been reported. $\Upsilon \delta \mathrm{T}$ cells, cytotoxic $\mathrm{T}$ cells, Th1 T cells, regulatory $\mathrm{T}$ cells (Tregs) and, more recently, Th17 cells have been implicated in the pathogenesis of BD [24].

T lymphocytes play a major role in mucosal immunity as the first line of host defence. Evidence of an increased proportion of activated $\mathrm{T}$ cells in $\mathrm{BD}$ has been reported $[25,26]$, and this change seems be crucial to the pathogenesis of the disease.

Natural killer T (NKT) cells have been implicated in the control of autoimmune diseases, as they too can regulate immune responses through cytokine production or cell/cell contact. Activated NK cells have been reported to be increased in active BD patients [27, 28].

IL8, a major chemokine that is known to activate leukocytes, has been assumed to represent a link between immune system activation and endothelial alterations in BD. An elevated level of IL8 was reported in the serum, skin lesions and small vessel endothelial cells of BD patients. Produced by T cells, IL8 has been correlated with disease activity and vascular involvement $[29,30]$.

An increase in Th1 cytokine production has been observed in the peripheral blood lesions of active BD patients (including ileal, mucocutaneous and skin lesions) [31-33]. Th1 cell infiltrates, including TNF $\alpha$, INF $\gamma$, IL8 and IL12, have been reported in oral and genital ulcers and in gastrointestinal lesions during $\mathrm{BD}[34,35]$.

Th17, a subset of $\mathrm{T}$ helper cells characterized by their production of IL17, has been isolated more recently and found to be implicated in many autoimmune/inflammatory disorders. IL17 promotes a neutrophil-mediated inflammatory response [36]. IL 23 acts to induce T cell activation to produce IL17 and is therefore one of the main Th17 pathway activators [37]. IL21 is a recently identified cytokine that is produced by central memory-activated CD4+ $\mathrm{T}$ cells and can drive Th17 differentiation or modulate Th1 and Tregs cells [38].

Tregs play a central role in protecting an individual from autoimmunity and have been widely studied in different autoimmune disorders [39, 40]. Activated Tregs are particularly decreased in BD patients. Still, the Tregs from BD patients were able to suppress effector cells, indicating their functionality [38].

Neutrophils are one of the major players of the innate immunity system. Neutrophil abnormalities have been extensively reported in $\mathrm{BD}$. In vivo, a priming state of neutrophils has been reported among BD patients. The role of $\mathrm{T}$ cells in neutrophil activation has been shown in experimental studies. High levels of proinflammatory cytokines, including IL8, INF $\gamma$ and $\mathrm{TNF} \alpha$, have been suggested to be responsible for the primed state of neutrophils [14]. Strikingly, Th17 cells are implicated in the up-regulation of the neutrophil inflammatory response [41]. Neutrophils are directly implicated in specific lesions of BD, given that the histopathological analysis of BD lesions shows venous and arterial neutrophilic infiltrates. The classification of $\mathrm{BD}$ as a neutrophilic vasculitis has been proposed [42], and the concept of the neutrophilic phlebitis has also been advocated [43].

Endothelial cells have pleiotropic functions to maintain the integrity of the vessels' lumens, keeping blood flow intact. Many studies have reported endothelial dysfunction in $\mathrm{BD}$. The endothelium is one of the main targets in BD, and endothelial dysfunction and activation have been clearly established [24].

Triggering factors, such as viruses, bacteria or molecular mimicry, are supposed to participate in the outbreak of BD. The perturbation of $\mathrm{T}$ cell homeostasis, especially that due to Th1 and Th17 expansion or decreased regulation by Tregs, is currently thought to be the cornerstone of BD pathogenesis. Inflammatory cytokines, such as IL21, thus play a critical role in the pathogenesis of BD. Inflammatory cells within BD inflammatory lesions have included mostly neutrophils and cytotoxic cells. Finally, endothelial dysfunction and activation have clearly been established (Fig. 2).

\section{CLINICAL MANIFESTATIONS}

At least two 'major' signs of the disease should be present to make the diagnosis. These major signs include aphthous-like ulcerations of the oral mucosa, genital ulcerations, and uveitis [44]. Other systems reported to be involved through the course of the disease are the skin, cardiovascular, pulmonary, gastrointestinal, and central nervous system. Despite being originally described as a dermatological disease, the major causes of morbidity and mortality result from ocular, major vascular and neurological involvement [45].

BD has been occasionally associated with inner ear involvement i.e., cochlear, retrocochlear and/or vestibular signs. According to Adler, these are rather rare and often overlooked complications of the disease and of other forms of systemic vasculitis, such as systemic lupus erythematosus, rheumatoid arthritis, Sjögren's syndrome, Wegener's granulomatosis, polyarteritis nodosa and giant cell arteritis [46].

Inner ear involvement in $\mathrm{BD}$ was first reported by Alajouanine et al. in 1961 [47]. Thereafter, cases of inner ear involvement were described in 1980 by Brama and Fainaru [48], followed by further reports from several authors [49, 50]. Our review of the literature discovered two systematic reviews reporting audio-vestibular dysfunction [51,52].

The otological features of $\mathrm{BD}$ can be divided into hearing loss and vertigo. One prospective study described sensorineural hearing loss in $27 \%$ of 72 patients with BD compared with $6 \%$ of controls [51]. Hearing and vestibular function were assessed in 20 patients with $\mathrm{BD}$ and 20 controls. Sudden sensorineural hearing loss was reported in two patients with BD. Audiovestibular dysfunction occurred in 15 patients but in only three controls. Cochlear dysfunction was more common than vestibular dysfunction, and cochlea and vestibular dysfunction could occur either singly or in combination [49]. 


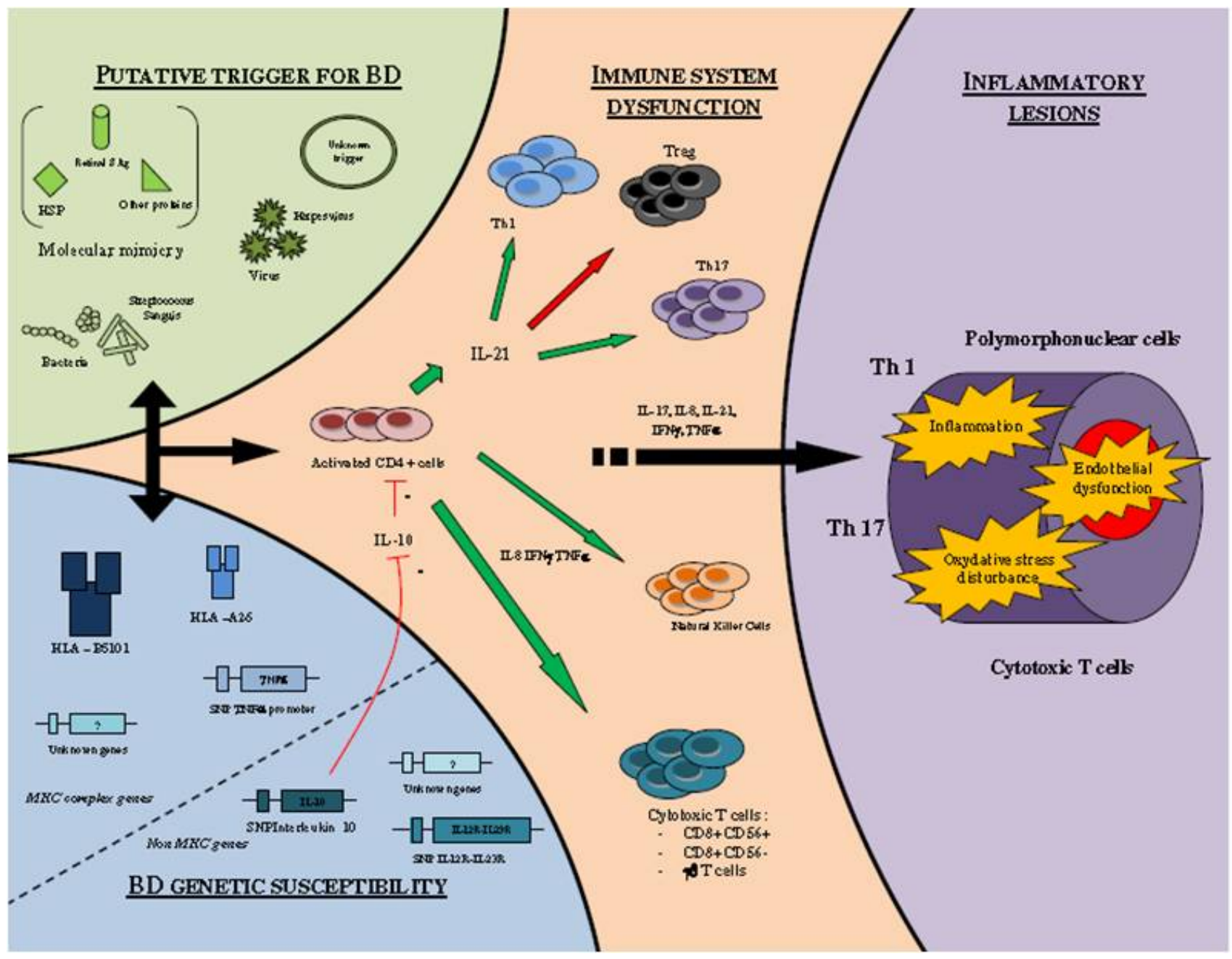

Fig. (2). Pineton de Chambrun M, Wechsler B, Geri G, Cacoub P, Saadoun D. New insights into the pathogenesis of Behçet's disease Autoimmunity Reviews 2012; 11: 687-698.

Vestibular involvement has been postulated after 16 of 25 patients with BD reported vertigo compared with no such problems in a control group. However, vestibulopathy was not confirmed by objective tests, and although Frenzel glasses were used to detect nystagmus, the results were not published within the paper [52].

Soylu et al. found that in their large series, the frequency of $\mathrm{HL}$ in $\mathrm{BD}$ was not as high as that reported in the literature [51].

By contrast, other authors [53-55] have reported that patients with BD show frequent audio-vestibular involvement with sensorineural hearing loss (SNHL). Sudden deafness occurring during exacerbation of the disease and hearing loss occurs more often in older patients and also in the complete form of BD. Audiological and vestibular examinations revealed an inner ear lesion. The patient had a positive glycerol test, suggesting endolymphatic hydrops. The pathological characteristic of $\mathrm{BD}$ is thought to be vasculitis, suggesting an association of autoimmune vasculitis with endolymphatic hydrops.

The incidence of hearing loss in $\mathrm{BD}$ has been reported to be 12 to $80 \%$ in several studies in the literature $[50,52,56,57]$.
However, most of these studies were performed on small groups of patients, and only a few of them had used control groups for statistical analysis [49, 52].

Bakhshaee observed a significant percentage $(59.2 \%)$ of hearing loss in the Behçet group compared with the control group (Table 1). Although no typical audiogram was observed in Behçet patients with hearing loss in most of the studies, there was a typical audiogram in which bilateral high-frequency SNHL with a down slope is the most common pattern (93.7\%) [58]. The presence of bilateral high-frequency SNHL with a down slope pattern in Behçet patients with hearing loss indicates the importance of performing an audiometric test. In paediatric cases, a hearing screening could be useful in early detection of this illness [59].

Brama and Fainaru reported that the inner ear involvement occurred more often in older Behçet patients, with a longer duration of the disease [48]. In the Bakhshaee study, hearing loss was the fourth most common manifestation of the disease after oral ulcers and eye and skin involvement; the fourth clinical symptom after oral and genital ulcers, and skin lesions in the study performed by 
Erdinç et al. [48, 60]; and the third symptom according to the studies performed by Brama and Faniaru, and Andreoli and Savastano [61].

Table 1. Clinical manifestations of Behçet's disease. Take from Erdinc AK E, Harputluoglu U, Oghan F, Baykal B. Behçet's Disease and Hearing Loss. Auris Nasus Larynx. 2004; 31: 29-33.

\begin{tabular}{|c|c|c|}
\hline & No. of Patients & \% \\
\hline \hline Oral ulcers & 27 & 100 \\
\hline Skin lesions & 19 & 70.37 \\
\hline Hearing loss & 16 & 59.26 \\
\hline Genital ulcers & 12 & 44.44 \\
\hline Anterior uveitis & 11 & 40.74 \\
\hline Arthritis & 10 & 37.037 \\
\hline Posterior uveitis & 9 & 33.3 \\
\hline Vascular & 4 & 14.81 \\
\hline Renal involvement & 2 & 7.41 \\
\hline Gastrointestinal & 2 & 7.41 \\
\hline Neurologic syndrome & 1 & 3.70 \\
\hline
\end{tabular}

In the reports by Elidan [50] and Gemignani [49], hearing loss was the fourth and fifth most common clinical manifestation, respectively. An interesting finding was the statistically significant lower frequency of the positive pathergy test in patients with hearing loss. That finding suggests that the pathergy test might be an indicator for showing the probability of hearing loss in patients with this disease. The pathergy test is a hyperreactivity of the skin to a needle prick and is a unique feature of $\mathrm{BD}$ [62].

The treatment of inner ear lesions remains unsatisfactory. Corticosteroids, vitamin B12, adenosine triphosphate, nicotinic acid and inhalation of oxygen have been used successfully in one case [54]. The combination of chlorambucil and corticosteroids led to improvement in another patient [63]. Sometimes early high-dose cortisone therapy (Betametason $4 \mathrm{mg}, 1 /$ daily) can be useful, and audiovestibular function can be completely recovered.

\section{DIFFERENTIAL DIAGNOSIS}

The diagnosis of BD is only supported by clinical criteria that require the exclusion of other diagnoses based on clinical presentation.

Oral ulceration is not specific for BD because it may occur in $30-40 \%$ of the general population. By contrast, bipolar ulcerations are more specific for BD. Oral ulcerations may also be associated with herpes simplex virus infection, hemopathy, HIV, Crohn's disease, systemic lupus erythematosus, bullous dermatosis or vitamin deficiencies.

In the case of recurrent uveitis sarcoidosis, Crohn's disease, Cogan syndrome [64], Vogt-Koyanagi-Harada syndrome [65] and infectious uveitis must be ruled out.

Audio-vestibular symptoms must be differentiated by sudden hearing loss [21, 22] and Ménière's disease [66].
Venous involvement should exclude antiphospholipid syndrome or thrombophilia. Arterial lesions of BD may mimic Takayasu's arteritis or polychondritis. Neuro-BD is sometimes difficult to distinguish from multiple sclerosis or tuberculosis. Lastly, chronic inflammatory bowel disorders must be ruled out in the case of gastrointestinal involvement [11].

\section{CONCLUSION}

The etiopathogenesis of BD remains unknown, but triggering factors, such as viruses, bacteria or molecular mimicry, in a genetically predisposed individual are thought to provoke the autoimmune process. The inflammatory cytokines, such as IL21, produced by activated CD4+ cells take on a critical role in determining perturbations in the $\mathrm{T}$ cell homeostasis, especially those involving Th1 and Th17 expansions or decreased regulation by Tregs. This phenomenon is now considered the most important event of $\mathrm{BD}$ pathogenesis. The inflammatory cells within the $\mathrm{BD}$ inflammatory lesions mostly consisted of neutrophils and the cytotoxic cells responsible for endothelial dysfunction.

Behçet's disease is usually considered to be a condition affecting the oral cavity, eyes, genitals and skin. However, some patients will also exhibit other ENT symptoms, particularly hearing loss. In these cases, Behçet's disease may present with features other than the classic triad of symptoms. Increased awareness of the clinical features within the head and neck region will hopefully enable early diagnosis and treatment of this potentially serious condition.

Patients with Behçet's disease may therefore present primarily to an otorhinolaryngologist. However, because of the rarity of the condition, the true diagnosis may not be considered.

In conclusion, inner ear involvement should be taken into consideration in the systematic clinical examination of patients with Behçet's disease. Whether inner ear involvement is associated with unfavourable prognosis remains unclear, and a specific therapy or prophylaxis for inner ear involvement is not known.

\section{CONFLICT OF INTEREST}

The authors confirm that this article content has no conflict of interest.

\section{ACKNOWLEDGEMENTS}

Declared none.

\section{REFERENCES}

[1] Sakane T, Takeno M, Suzuki N, Inaba G. Behçet's disease. N Engl J Med 1999; 341: 1284-91.

[2] Feigenbaum A. Description of Behçet's syndrome in the Hippocratic third book of endemic diseases. Br J Ophthalmol 1956; 40: 355-7.

[3] Behçet H. Uber rezidivierende, aphthose, durch ein virus verursachte Geschwure am Mund, am Auge und an den Genitalien. Dermatol Wochenschr 1937; 105: 1152-7.

[4] Behçet H. Considerations sur les lesions aphteuses de la bouche et des parties genitals, ainsi que sur les manifestations oculaires d'origine probablement virutique et observations concernant leur foyer d'infection. Bull Soc Fr Dermatol Syphiligr 1938; 45: 420-33.

[5] Dilsen N. History and development of Behçet's disease. Rev Rhum Engl Ed 1996; 63: 512-9. 
[6] Levine JA, O’Duffy JD. Pseudo Behçet's syndrome a description of twenty-three cases. In: Godeau P, Wechsler B, Eds. Behçet's disease: Proceedings of the Sixth International Conference on Behçet's disease, held in Paris, France, June 30 to July 1, 1993. Amsterdam: Elsevier Science Publishers 1993.

[7] Verity DH, Marr JE, Ohno S, Wallace GR, Stanford MR. Behçet's disease, the Silk Road and HLA-B51: historical and geographical perspectives. Tissue Antigens 1999; 54: 213-20.

[8] Bang D, Lee ES, Lee S. Behçet's disease. In: Eun HC, Kim SC, Lee WS, Eds. Asian Skin and Skin Diseases: special book of the $22^{\text {nd }}$ World Congress of Dermatology, held in Seoul, Korea from May 24-29, 2011. Seoul: MEDrang Inc; 2011.

[9] Davatchi F, Shahram F, Chams-Davatchi C, et al. Behçet's disease: from East to West. Clin Rheumatol 2010; 29: 823-33.

[10] Chung YL, Bang DS, Lee ES, Lee SN, Mok JW, Park KS. Behçet's disease: the first Mongolian case in literature showing HLA-B51, MICA gene type *5/*6. Yonsei Med J 2003; 44: 935-58.

[11] Saadoun D, Wechsler B. Behcet's disease. Orphanet J Rare Dis 2012; 7: 20

[12] Akpolat T, Akkoyunlu M, Akpolat I, Dilek M, Odabas AR, Ozen S. Renal Behçet's disease: a cumulative analysis. Semin Arthritis Rheum 2002; 31: 317-37.

[13] Saadoun D, Wechsler B, Desseaux K, et al. Mortality in Behçet's disease. Arthritis Rheum 2010; 62: 2806-12.

[14] Pay S, Simsek I, Erdem H, Dinc A. Immunopathogenesis of Behçet's disease with special emphasize to the possible role of antigen presenting cells. Rheumatol Int 2007; 27: 417-24.

[15] Kulaber A, Tugal-Tutkun I, Sibel P, et al. Pro-inflammatory cellular immune response in Behçet's disease. Rheumatol Int 2007; 27: 1113-8.

[16] Geraghty D, Inoko H, Rowen L. Complete sequence and gene map of a human major histocompatibility complex. The MHC sequencing consortium. Nature 1999; 401: 921-3.

[17] Zouboulis CC, Kotter I, Djawari D, et al. Epidemiological features of Adamantiades Behçet's disease in Germany and in Europe. Yonsei Med J 1997; 38: 411-22.

[18] Lehner $\mathrm{T}$. The role of heat shock protein, microbial and autoimmune agents in the aetiology of Behçet's disease. Int Rev Immunol 1997; 14: 21-32.

[19] Direskeneli H. Behçet's disease: infectious aetiology, new autoantigens, and HLA-B51. Ann Rheum Dis 2001; 60: 996-1002.

[20] Mendes D, Correia M, Barbedo M, et al. Behçet's disease-a contemporary review. J Autoimmun 2009; 32: 178-88

[21] Greco A, Fusconi M, Gallo A, Marinelli C, Macri GF, de Vincentiis M. Sudden sensorineural hearing loss: an autoimmune disease? Autoimmun Rev 2011; 10: 756-61.

[22] Fusconi M, Chistolini A, de Virgilio A, et al. Sudden sensorineural hearing loss: a vascular cause? Analysis of prothrombotic risk factors in head and neck. Int J Audiol 2012; 51: 800-5.

[23] Mendoza-Pinto C, García-Carrasco M, Jiménez-Hernández M, et al. Etiopathogenesis of Behçet's disease. Autoimmun Rev 2010; 9: 241-5.

[24] Pineton de Chambrun M, Wechsler B, Geri G, Cacoub P, Saadoun D. New insights into the pathogenesis of Behçet's disease. Autoimmun Rev 2012; 11: 687-98.

[25] Freysdottir J, Hussain L, Farmer I, Lau SH, Fortune F. Diversity of gammadelta $\mathrm{T}$ cells in patients with Behcet's disease is indicative of polyclonal activation. Oral Dis 2006; 12: 271-7.

[26] Van Hagen PM, Hooijkaas H, Vd Beemd MW, Verjans G, Baarsma GS. T-gammadelta receptor restriction in peripheral lymphocytes of patients with Behcet's disease. Adv Exp Med Biol 2003; 528: 267-8.

[27] Yamaguchi Y, Takahashi H, Satoh T, et al. Natural killer cells control a T-helper 1 response in patients with Behcet's disease. Arthritis Res Ther 2010; 12: R80.

[28] Hamzaoui K, Ayed K, Hamza M, Touraine JL. Natural killer cells in Behcet's disease. Clin Exp Immunol 1988; 71: 126-31.

[29] Zouboulis CC, Katsantonis J, Ketteler R, et al. AdamantiadesBehcet's disease: interleukin- 8 is increased in serum of patients with active oral and neurological manifestations and is secreted by small vessel endothelial cells. Arch Dermatol Res 2000; 292: 279-84.

[30] Durmazlar SP, Ulkar GB, Eskioglu F, Tatlican S, Mert A, Akgul A. Significance of serum interleukin-8 levels in patients with Behcet's disease: high levels may indicate vascular involvement. Int $\mathbf{J}$ Dermatol 2009; 48: 259-64.
[31] Imamura Y, Kurokawa MS, Yoshikawa H, et al. Involvement of Th1 cells and heat shock protein 60 in the pathogenesis of intestinal Behcet's disease. Clin Exp Immunol 2005; 139: 371-8.

[32] Ben Ahmed M, Houman H, Miled M, Dellagi K, Louzir H. Involvement of chemokines and Th1 cytokines in the pathogenesis of mucocutaneous lesions of Behcet's disease. Arthritis Rheum 2004; 50: 2291-5.

[33] Ilhan F, Demir T, Turkcuoglu P, Turgut B, Demir N, Godekmerdan A. Th1 polarization of the immune response in uveitis in Behcet's disease. Can J Ophthalmol 2008; 43: 105-8.

[34] Dalghous AM, Freysdottir J, Fortune F. Expression of cytokines, chemokines, and chemokine receptors in oral ulcers of patients with Behcet's disease (BD) and recurrent aphthous stomatitis is Th1-associated, although Th2-association is also observed in patients with BD. Scand J Rheumatol 2006; 35: 472-5.

[35] Ferrante A, Ciccia F, Principato A, et al. A Th1 but not a Th17 response is present in the gastrointestinal involvement of Behcet's disease. Clin Exp Rheumatol 2010; 28: S27-30.

[36] Direskeneli H, Fujita H, Akdis CA. Regulation of $\mathrm{T}(\mathrm{H}) 17$ and regulatory $\mathrm{T}$ cells in patients with Behcet disease. J Allergy Clin Immunol 2011; 128: 665-6.

[37] Parham C, Chirica M, Timans J, et al. A receptor for the heterodimeric cytokine IL-23 is composed of IL-12Rbeta1 and a novel cytokine receptor subunit, IL-23R. J Immunol 2002; 168: 5699-708.

[38] Geri G, Terrier B, Rosenzwajg M, et al. Critical role of IL-21 inmodulating $\mathrm{T}(\mathrm{H}) 17$ and regulatory $\mathrm{T}$ cells in Behcet disease. J Allergy Clin Immunol 2011; 128: 655-64.

[39] Miyara M, Sakaguchi S. Human Fox P3(+) CD4(+) regulatory T cells: their knowns and unknowns. Immunol Cell Biol 2011; 89: 346-51.

[40] Buckner JH. Mechanisms of impaired regulation by CD4(+) $\mathrm{CD} 25(+)$ FOXP3(+) regulatory $\mathrm{T}$ cells in human autoimmune diseases. Nat Rev Immunol 2010; 10: 849-59.

[41] Ekinci NS, Alpsoy E, Karakas AA, Yilmaz SB, Yegin O. IL-17A has an important role in the acute attacks of Behcet's disease. J Invest Dermatol 2010; 130: 2136-8.

[42] Kobayashi M, Ito M, Nakagawa A, et al. Neutrophil and endothelial cell activation in the vasa vasorum in vasculo-Behcet disease. Histopathology 2000; 36: 362-71.

[43] Hayasaki N, Ito M, Suzuki T, et al. Neutrophilic phlebitis is characteristic of intestinal Behcet's disease and simple ulcer syndrome. Histopathology 2004; 45: 377-83.

[44] Helm TN, Camisa C, Allen C, Lowder C. Clinical features of Behçet's disesase: a report of four cases. Oral Surg Oral Med Oral Pathol 1991; 72: 30.

[45] Erdinc AK, Harputluoglu U, Oghan F, Baykal B. Behçet's disease and hearing loss. Auris Nasus Larynx 2004; 31: 29-33.

[46] Adler YD, Jovanovic S, Jivanjee A, Krause L, Zouboulis CC. Adamantiades-Behçet's disease with inner ear involvement. Clin Exp Rheumatol 2002; 20(Suppl 26): S40-2.

[47] Alajouanine T, Castaigne P, Lhermitte F, Cambier J, Gautier JC. The meningoencephalitis of Behçet's disease. Presse Med 1961; 69: 2579-82.

[48] Brama I, Fainaru M. Inner ear involvement in Behçet's disease. Arch Otolaryngol 1980; 106: 215-7.

[49] Gemignani G, Berrettini S, Bruschini P, et al. Hearing and vestibular disturbances in Behçet's syndrome. Ann Otol Rhinol Laryngol 1991; 100: 459-62.

[50] Elidan J, Levi H, Cohen E, Ben Ezra D. Effect of cyclosporine A on hearing loss in Behçet's disease. Ann Otol Rhinol Laryngol 1991; 100: 464-8.

[51] Soylu L, Aydogan B, Soylu M, Ozsahinoglu C. Hearing loss in Behçet's disease Ann Otol Rhinol Laryngol 1995; 104: 864-7.

[52] Everekliogu C, Cokkeser Y, Doganay S, Er H, Kizilay A. Audiovestibular evaluation in patients with Behçet's syndrome. J Laryngol Otol 2001; 115: 704-8.

[53] Berrettini S, Bruschini P, Sellari Franceschini S, Mita L, Olivieri I, Gemignani G. Sudden deafness and Behçet's disease. Acta Otorhinolaryngol Belg 1989; 43: 221-9.

[54] Igarashi Y, Watanabe Y, Aso S. A case of Behçet's disease with otologic symptoms. ORL J Otorhinolaryngol Relat Spec 1994; 56 295-8.

[55] Webb CJ, Moots RJ, Swift AC. Ear, nose and throat manifestations of Behçet's disease: a review. J Laryngol Otol 2008; 122: 1279-83. 
[56] Choung YH, Cho MJ, Park K, Choi SJ, Shin YR, Lee ES. Audiovestibular disturbance in patients with Behçet's disease. Laryngoscope 2006; 116: 1987-90.

[57] Kulahli I, Balci K, Koseoglu E, Yuce I, Cagli S, Senturk M. Audiovestibular disturbances in Behçet's patients: report of 62 cases. Hear Res 2005; 203: 28-31.

[58] Bakhshaee M, Ghasemi MM, Hatef MR, Talebmehr M, Shakeri MT. Hearing loss in Behçet syndrome. Otolaryngol Head Neck Surg 2007; 137: 439-42

[59] Bubbico L, Tognola G, Greco A, Grandori F. Universal newborn hearing screening programs in Italy: survey of year 2006. Acta Otolaryngol 2008; 128: 1329-36.

[60] AK E, Harputluoglu U, Oghan F, Baykal B. Behçet's disease and hearing loss. Auris Nasus Larynx 2004; 31: 29-33.
[61] Andreoli C, Savastano M. Audiologic pathology in Behçet syndrome. Am J Otol 1989; 10: 466-7.

[62] Ozdemir M, Balevi S, Deniz F, Mevlitoğlu I. Pathergy reaction in different body areas in Behçet's disease. Clin Exp Dermatol 2007; 32: 85-7.

[63] Schwanitz HJ, Knop J, Bonsman G. Morbus Behçet mit Innenohrbeteiligung. Z Hautkr 1984; 59: 1173-4.

[64] Greco A, Gallo A, Fusconi M, et al. Cogan's syndrome: an autoimmune inner ear disease. Autoimmun Rev 2013; 12: 396-400.

[65] Greco A, Fusconi M, Gallo A, et al. Vogts-Koyanagi-Harada syndrome. Autoimmun Rev 2013; 12(11): 1033-8.

[66] Greco A, Gallo A, Fusconi M, Marinelli C, Macri GF, de Vincentiis M. Meniere's disease might be an autoimmune condition? Autoimmun Rev 2012; 11: 731-8.

(C) Greco et al.; Licensee Bentham Open.

This is an open access article licensed under the terms of the Creative Commons Attribution Non-Commercial License (http://creativecommons.org/licenses/by-nc/3.0/) which permits unrestricted, non-commercial use, distribution and reproduction in any medium, provided the work is properly cited. 